ECLETICA A

Volume 28 (2003) número 1

UNiESP

$\underline{\text { www.scielo.br/eq }}$

\title{
INFLUENCE OF THE AI CONTENT ON THE PHASE TRANSFORMATIONS IN Cu-Al-Ag ALLOYS
}

\author{
A. T. ADORNO ${ }^{\prime}$; A. V. BENEDETTI'; R. A. G. da SILVA ${ }^{l}$; M. BLANCO
}

\begin{abstract}
The influence of the $\mathrm{Al}$ content on the phase transformations in $\mathrm{Cu}-\mathrm{Al}-\mathrm{Ag}$ alloys was studied by classical differential thermal analysis (DTA), optical microscopy (OM) and X-ray diffractometry (XRD). The results indicated that the increase in the $\mathrm{Al}$ content and the presence of $\mathrm{Ag}$ decrease the rate of the $\beta 1$ phase decomposition reaction and contribute for the raise of this transition temperature, thus decreasing the stability range of the perlitic phase resulted from the b1 decomposition reaction.
\end{abstract}

Keywords: phase transitions; martensitic transformation; $\mathrm{Cu}-\mathrm{Al}-\mathrm{Ag}$ alloys.

\section{Introduction}

The literature about alloys of the $\mathrm{Cu}-\mathrm{Al}$ system is extensive, due to its practical use. These alloys are of low cost and present good strength and hardness, depending on the Al content. They are used for making sleeves, guides, seats, flanges, gear wheels and many other critical small parts, as electrolysis cell cathodes, circuit plates and casting moulds when high thermal conductivity is needed. $\mathrm{Cu}-\mathrm{Al}$ alloys with concentration in the range from 9 to $14 \mathrm{wt} . \% \mathrm{Al}$ contain in their structure the $(\alpha+\gamma 1)$ eutectoid, which is formed through decomposition of the $\beta$ phase. On rapid cooling from high temperatures, the $\beta$ phase undergoes a martensitic transformation. When quenched from the $\beta$ state, alloys containing more than about $11 \mathrm{wt} . \% \mathrm{Al}$ first become ordered to the $\beta_{1}$ phase and then transform martensitically to either $\beta_{1}{ }^{\prime},\left(\beta_{1}{ }^{\prime}+\gamma^{\prime}\right)$ or $\gamma^{\prime}$, depending on the $\mathrm{Al}$ content. In alloys with less than $11 \mathrm{wt} . \% \mathrm{Al}$ the $\beta$ phase transforms to an fcc type of disordered martensite [8]. Silver additions to the $\mathrm{Cu}-\mathrm{Al}$ alloys increase its hardness [4] and improves the resistance to stress corrosion [1], without changing significantly the plasticity and workability of the alloys.

In this work, the influence of the $\mathrm{Al}$ content on the phase transformations of $\mathrm{Cu}-\mathrm{Al}-\mathrm{Ag}$ alloys was studied by classical differential thermal analysis (DTA), optical microscopy (OM) and X-ray diffractometry (XRD), and the results were compared with those found in the literature ${ }^{[2]}$

\section{Experimental}

The Cu-9\%wt.Al-4wt.\%Ag, Cu10wt.\%Al-4wt.\%Ag and Cu-11wt.\%Al-4wt.\%Ag alloys were prepared in an induction furnace under

1 Departamento de Físico-Química - Instituto de Química - Unesp

Caixa Postal 355 - CEP 14801-970 -Araraquara-SP - Brasil. 
argon atmosphere using $99.95 \%$ starting materials and graphite crucible. Results from chemical analysis indicated a final alloy composition very close to the nominal one. Small cylinders of about $10 \mathrm{~mm}$ length and $5.0 \mathrm{~mm}$ diameter were used for DTA analysis and flat square samples of about 10 mm were obtained for metallography and XRD. These samples were initially annealed for $120 \mathrm{~h}$ at $850^{\circ} \mathrm{C}$ for homogenization and after annealing some of them were equilibrated for one hour at $850{ }^{\circ} \mathrm{C}$ and quenched in iced water. The XRD diagrams were obtained using a Siemens D5000 X-ray diffractometer. After the heat treatments the flat samples were polished, etched and examined in a Leica DMR optical microscope.

DTA curves were obtained using a sample holder with two Ni/Cr-Ni/Al thermocouples, one of which was introduced in the sample and the other in a pure copper cylinder with the same sample dimensions. The sample holder, inside a Vycor tube, was introduced in a furnace and the thermocouples terminals were connected to a HP 34404A multimeter. The heating rate and the data acquisition were controlled using a MQ 112 MicroQuímica interface.

\section{Results and discussion}

Figure 1 shows the DTA curves obtained at a heating rate of $20{ }^{\circ} \mathrm{Cmin}^{-1}$ for the $\mathrm{Cu}-9 \mathrm{wt} . \% \mathrm{Al}-$ 4wt.\%Ag (curve a), Cu-10wt.\%Al-4wt.\%Ag (curve b) and $\mathrm{Cu}-11 \mathrm{wt} . \% \mathrm{Al}-4 \mathrm{wt} . \% \mathrm{Ag}$ (curve c) alloys annealed at $850{ }^{\circ} \mathrm{C}$ for 120 hours. In curves (a) and (b) five endothermic peaks were observed, while in curve (c) only three peaks were detected. Peak P1, at about $559^{\circ} \mathrm{C}$, is due to the $\alpha+\gamma_{1} \leftrightarrow \beta$ eutectoid transformation [10], as expected from the $\mathrm{Cu}-\mathrm{Al}$ equilibrium diagram [9]. The endothermic peak $\mathrm{P}_{2}$, at about $508{ }^{\circ} \mathrm{C}$, is associated to the $\beta_{1}$ phase disordering. The martensitic phase $\beta_{1}$ ' changes into the $\beta_{1}$ phase in the same temperature interval of the $\alpha_{2}$ phase disordering process and at about $508^{\circ} \mathrm{C}$ the $\beta_{1}$ phase transforms into the $\beta$ phase [7]. Peak $\mathrm{P}_{3}$, at about $380{ }^{\circ} \mathrm{C}$, is associated to the dissolution of the $\alpha_{2}$ phase precipitates formed during slow cooling [4]. The peak $\mathrm{P}_{4}$, which is observed at about $330^{\circ} \mathrm{C}$ in curve (a) and $270{ }^{\circ} \mathrm{C}$ in curve (b), corresponds to the $\alpha+\alpha_{2} \rightarrow \alpha+\gamma_{1}$ order-disorder transition 6 and peak $\mathrm{P}_{5}$, observed at about $220^{\circ} \mathrm{C}$ in curve (a) and $170^{\circ} \mathrm{C}$ in curve (b) corresponds to the beginning of the $\alpha_{2}$ phase disordering [2]. Peaks $\mathrm{P}_{4}$ and $\mathrm{P}_{5}$ were not detected in curve (c). It is possible to observe, in fig. 1, that the intensity of peak $P_{1}$ increases with the $\mathrm{Al}$ concentration and that its temperature is shifted to lower values, when compared with the temperature for samples without Ag addition [2]. This temperature shift may be associated to the $\mathrm{Ag}$ dissolution in the matrix, which increases the $\alpha$ phase relative fraction and facilitates the formation of the $\beta$ phase from the combination of the remaining $\alpha$ with the perlitic phase. The increase in the intensity of peak $\mathrm{P}_{1}$ may be due to the increase in the Al concentration, which causes an increase in the relative fraction of the $\gamma_{1}$ phase.

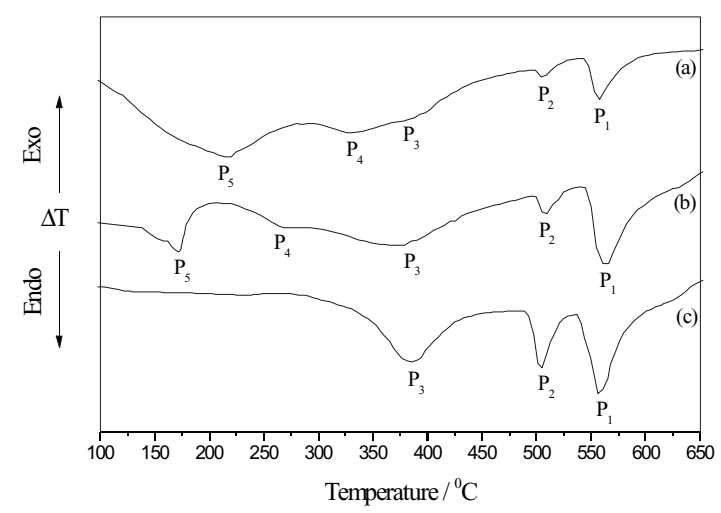

Figure 1. DTA curves obtained after annealing: (a) $\mathrm{Cu}-9 \% \mathrm{Al}-4 \% \mathrm{Ag}$ alloy; (b) $\mathrm{Cu}-10 \% \mathrm{Al}-4 \% \mathrm{Ag}$ alloy and (c) $\mathrm{Cu}-11 \% \mathrm{Al}-4 \% \mathrm{Ag}$ alloy. Heating rate $20{ }^{\circ} \mathrm{C} \mathrm{min}^{-1}$.

Peak $\mathrm{P}_{2}$ is also shifted to lower temperatures, compared with samples without $\mathrm{Ag}$ additions, and its intensity increases with Al concentration. The shift and intensity increase may be related to the combined effects of $\mathrm{Al}$ concentration increase, which facilitates the $\beta_{1}$ phase rosettes formation [5] and the aftereffect of $\beta$ phase formation from $\beta_{1}$, and of the presence of $\mathrm{Ag}$, which seems to increase the relative fraction of the $\beta_{1}$ ' martensitic phase retained in samples cooled at a rate higher than $2{ }^{\circ} \mathrm{Cmin}^{-1}$. Peak $\mathrm{P}_{3}$ intensity increases with the increase in the $\mathrm{Al}$ content, due to the greater $a_{2}$ relative fraction. The presence of Ag seems not to interfere in this transformation, because it is observed at the same temperature as the samples without Ag. Peaks $\mathrm{P}_{4}$ and $\mathrm{P}_{5}$ are shifted to lower temperatures with the increase in the $\mathrm{Al}$ concentration, and for the $\mathrm{Cu}-11 \mathrm{wt} . \% \mathrm{Al}-$ 4wt.\%Ag (curve c) they are not detected.

Ecl. Quím., São Paulo, 28(1): 33-38, 2003 


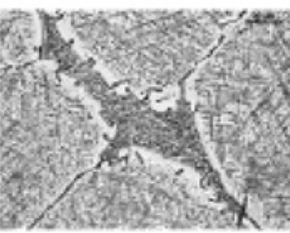

(a)

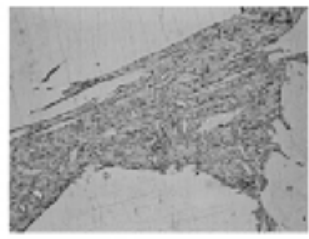

(b)

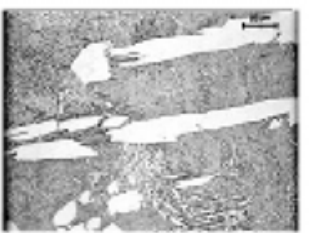

(c)

Figure 2. Optical micrographs (500x) obtained for the alloys after annealing: (a) $\mathrm{Cu}-9 \% \mathrm{Al}-4 \% \mathrm{Ag}$; (b) $\mathrm{Cu}-$ $10 \% \mathrm{Al}-4 \% \mathrm{Ag}$; (c) $\mathrm{Cu}-11 \% \mathrm{Al}-4 \% \mathrm{Ag}$.

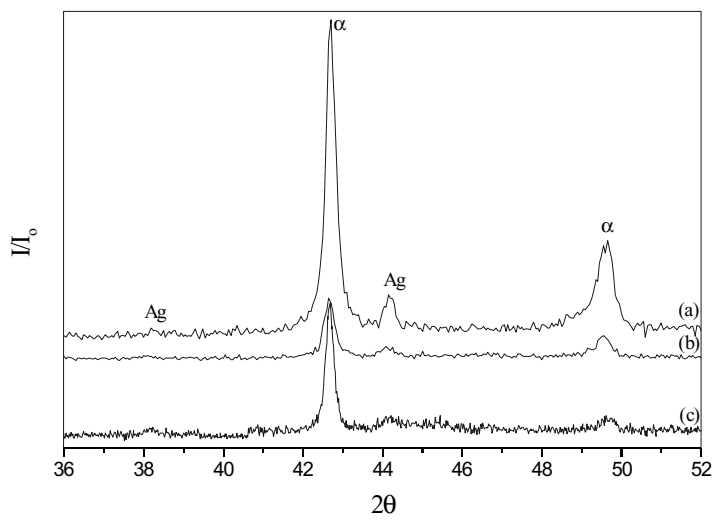

Figure 3. X-ray diffraction patterns obtained for the alloys after annealing: (a) $\mathrm{Cu}-9 \% \mathrm{Al}-4 \% \mathrm{Ag}$; (b) $\mathrm{Cu}-$ $10 \% \mathrm{Al}-4 \% \mathrm{Ag}$; (c) $\mathrm{Cu}-11 \% \mathrm{Al}-4 \% \mathrm{Ag}$.

The starting point of the DTA curves in fig. 1 corresponds to the perlitic phase, as observed in the optical micrographs of figure 2. At this point there is also an amount of $\mathrm{Ag}$ remaining from the solution treatment, as showed in the X-ray diffraction patterns of figure 3 . The micrographs of fig. 2 seems to confirm that the increase in the $\mathrm{Al}$ content decreases the relative fraction of $\alpha$ phase and promotes the perlitic phase formation.

Figure 4 shows the DTA curves obtained at a heating rate of $20^{\circ} \mathrm{Cmin}^{-1}$ for the $\mathrm{Cu}-9 \mathrm{wt} . \% \mathrm{Al}-$ 4wt.\%Ag (curve a), Cu-10wt.\%Al-4wt.\%Ag (curve b) and $\mathrm{Cu}-11 \mathrm{wt} . \% \mathrm{Al}-4 \mathrm{wt} . \% \mathrm{Ag}$ (curve c) alloys quenched from $850^{\circ} \mathrm{C}$. In the curves of fig. 4 the endothermic peak $\mathrm{P}_{1}$, at about $559^{\circ} \mathrm{C}$, is due to the $\alpha+\gamma_{1} \leftrightarrow \beta$ eutectoid transformation [10] and the endothermic peak $\mathrm{P}_{2}$, at about $525^{\circ} \mathrm{C}$, is attributed to the $\beta_{1} \rightarrow \beta$ transition from the remaining part of the $\beta_{1}$ phase formed at low temperature [8]. The endothermic peak $\mathrm{P}_{3}$, at about $480^{\circ} \mathrm{C}$, is associated to the reverse martensitic transformation and to the $\beta_{1} \rightarrow \alpha+\gamma_{1}$ decomposition from part of the $\beta_{1}$ phase. Peak $\mathrm{P}_{3}$ was not detected in curves (a) and (b). The exothermic peak $\mathrm{P}_{4}$, at about $400{ }^{\circ} \mathrm{C}$, may be associated to the precipitation of $\mathrm{Ag}$ dissolved in the matrix [3]. $\mathrm{P}_{5}$ is due to the ordering of the martensitic $\beta$ ' phase remaining from the $\beta^{\prime} \rightarrow \beta_{1}$ ' transformation and to the end of the $\alpha_{2}$ phase ordering [2]. $\mathrm{P}_{6}$ may be associated to the beginning of the $\alpha$ phase ordering. Peak $\mathrm{P}_{1}$ in fig. 4 seems to undergo the same changes observed for the corresponding peak in fig. 1. It is possible to observe an increase in the intensity of peak $\mathrm{P}_{2}$ in fig. 4 , but the transition temperature is very close to the expected one [2]. Comparing to the transition for the annealed sample (fig. 1), this phase transition is now the dominant effect for the quenched samples, in the temperature range considered. This must be associated to the increase in the martensitic phase retained at fast cooling. This peak temperature is close to that observed for samples without Ag addition, indicating that the effect of the presence of $\mathrm{Ag}$ has been minimized by the heat treatment. Peak $\mathrm{P}_{3}$, observed at about $480{ }^{\circ} \mathrm{C}$ in curve (c) of fig. 4 , is observed at about $380^{\circ} \mathrm{C}$ in $\mathrm{Cu}-\mathrm{Al}$ alloys [2], indicating that the increase in the $\mathrm{Al}$ concentration and the presence of $\mathrm{Ag}$ are decreasing the $\beta_{1}$ phase decomposition reaction rate and contributing to the increase in the temperature transition. Thus it causes a decrease on the stability range of the perlitic phase produced by the $\beta_{1}$ phase decomposition. As the $\beta_{1}{ }^{\prime} \rightarrow \beta_{1}$ $\rightarrow \beta$ transition and the $\beta_{1}$ phase decomposition occur in the same temperature interval, it is also observed an increase in the stability range of the martensitic phase with the $\mathrm{Al}$ concentration and the presence of Ag. Peak $\mathrm{P}_{4}$ seems to indicate that the beginning of the $\beta_{1}$ phase decomposition may be related to Ag precipitation. It is known that $\mathrm{Ag}$ diffusion in the $\gamma_{1}$ phase is greater than in the $\alpha$ phase, due to changes in the atomic density [11]. In this way, Ag precipitation must occur mainly on the perlitic phase and this seems to indicate that 
the $\beta_{1}$ phase decomposition catalyzes the $\mathrm{Ag}$ precipitation reaction. The absence of the exothermic peak $\mathrm{P}_{4}$ in curve (a) seems to indicate that this thermal event is occurring in the same temperature range of the endothermic peak $\mathrm{P}_{3}$, and that the enthalpic variations are similar, causing the absence of both thermal events. Peak $\mathrm{P}_{5}$ is observed at about $290^{\circ} \mathrm{C}$ in alloys with 9 and $10 \mathrm{wt} . \% \mathrm{Al}$ and is associated to the martensitic ordering reaction [2] and is not observed in curve (a) of fig. 4, indicating that the presence of $\mathrm{Ag}$ disturbs the $\beta$ ' phase ordering process. In curve $4-b$ this peak was observed at about the same temperature as that for the alloy without $\mathrm{Ag}$ addition.

The starting point of the DTA curves of fig. 4 corresponds to the martensitic phase, as showed by the micrographs in figure 5 . It is known [12] that alloys with less than $10.8 \mathrm{wt} . \% \mathrm{Al}$ must show the $\beta$ ' type martensitic phase and that over this concentration the martensitic phase observed is the $\beta_{1}$ '. The micrographs in fig. 5 show the presence of the $\beta_{1}$ ' martensitic phase in the $\mathrm{Cu}-10$ wt.\%Al alloy. It seems to indicate that the addition of 4 wt.\%Ag shifts the equilibrium concentration to higher $\mathrm{Al}$ contents. The presence of the $\beta_{1}$, martensitic phase in the $\mathrm{Cu}-10$ wt.\%Al-4 wt.\%Ag alloy indicates that the dominant effect, in the temperature range where peak $\mathrm{P}_{5}$ is detected, is the end of the $\alpha$ phase ordering process. In curve 4-c this final step is shifted to higher temperatures, probably due to some interaction of the $\alpha$ phase with Ag.

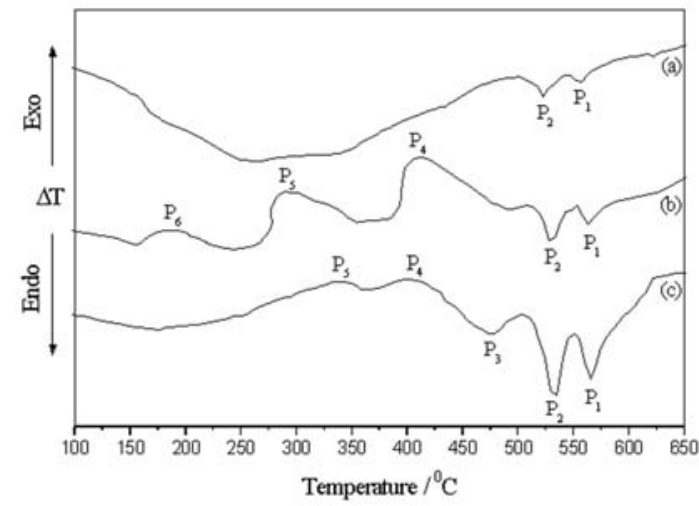

Figure 4. DTA curves obtained for alloys initially quenched: (a) $\mathrm{Cu}-9 \% \mathrm{Al}-4 \% \mathrm{Ag}$; (b) $\mathrm{Cu}-10 \% \mathrm{Al}-$ $4 \% \mathrm{Ag}$; (c) $\mathrm{Cu}-11 \% \mathrm{Al}-4 \% \mathrm{Ag}$. Heating rate $20{ }^{\circ} \mathrm{Cmin}-1$

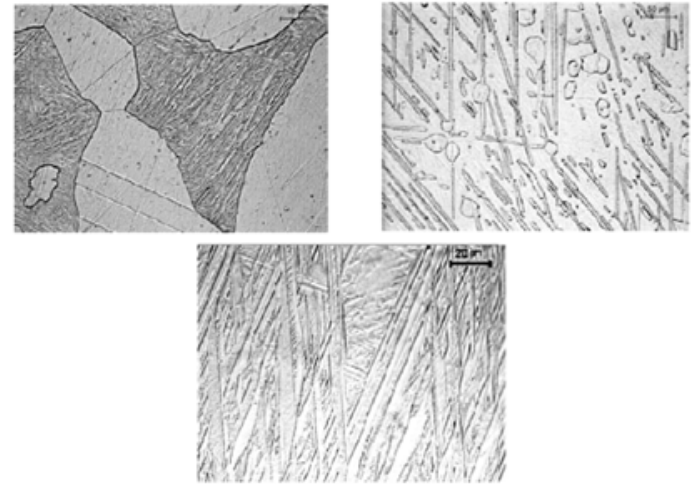

Figure 5. Optical micrographs (500x) obtained for alloys quenched from $850 \mathrm{oC}$ : (a) $\mathrm{Cu}-9 \% \mathrm{Al}-4 \% \mathrm{Ag}$; (b) $\mathrm{Cu}-10 \% \mathrm{Al}-4 \% \mathrm{Ag}$; (c) $\mathrm{Cu}-11 \% \mathrm{Al}-4 \% \mathrm{Ag}$.

In the micrographs of figure 6 it is possible to observe the phase transformations sequence occurring in the $\mathrm{Cu}-10$ wt.\%Al-4 wt.\%Ag alloy initially quenched from $850 \mathrm{oC}$ and then successively quenched in the temperature range from 300 to $950 \mathrm{oC}$. These micrographs seems to confirm what was proposed in the discussions of fig. 4. In the X-ray diffraction patterns showed in figure 7 it is possible to observe that the proposed sequence is in good agreement to that expected from the $\mathrm{Cu}-\mathrm{Al}$ equilibrium diagram [9], and that this sequence of transformations is not modified by the presence of Ag.

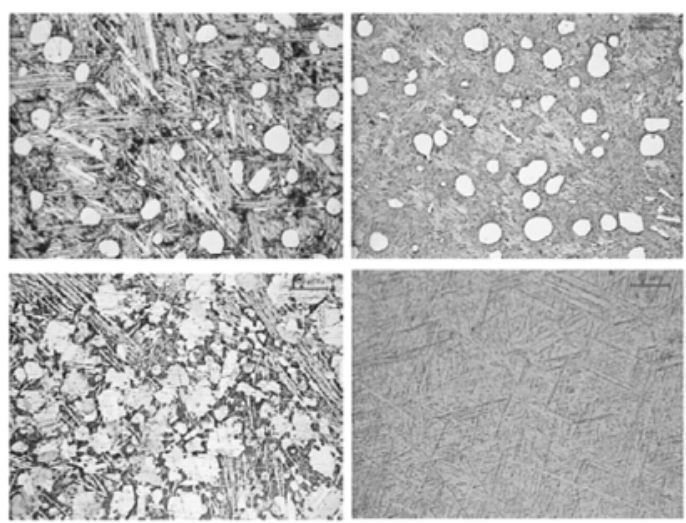

Figure 6. Optical micrographs (200x) obtained for the $\mathrm{Cu}-10 \% \mathrm{Al}-4 \% \mathrm{Ag}$ alloy initially quenched from 850 ${ }^{\circ} \mathrm{C}$ and then quenched from: (a) $300{ }^{\circ} \mathrm{C}$; (b) $400{ }^{\circ} \mathrm{C}$; (c) 600 ${ }^{\circ} \mathrm{C}$ and (d) $950{ }^{\circ} \mathrm{C}$. 

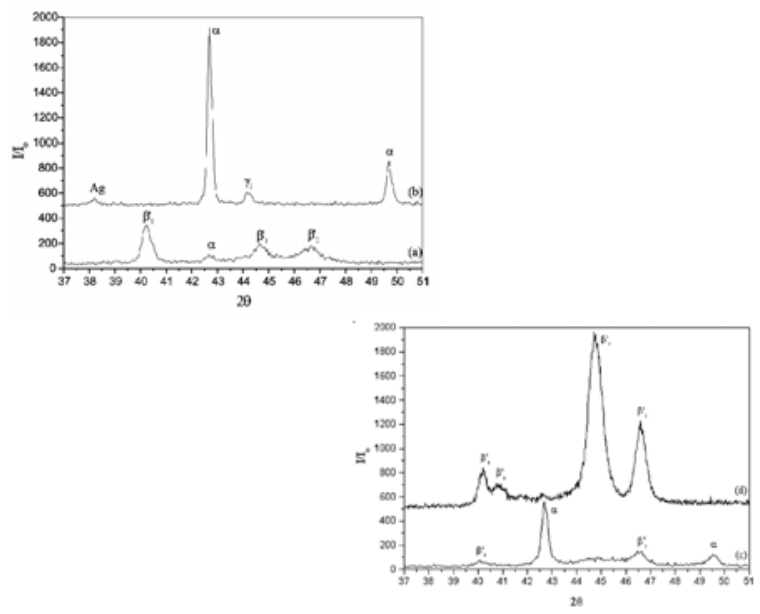

Figure 7. X-ray diffraction patterns obtained for the $\mathrm{Cu}-10 \% \mathrm{Al}-4 \% \mathrm{Ag}$ alloy initially quenched from 850 ${ }^{\circ} \mathrm{C}$ and then quenched from: (a) $300{ }^{\circ} \mathrm{C}$; (b) $500{ }^{\circ} \mathrm{C}$; (c) 600 ${ }^{\circ} \mathrm{C}$ and (d) $950{ }^{\circ} \mathrm{C}$.

\section{Conclusions}

The results indicate that with the addition of 4 wt.\%Ag to the $\mathrm{Cu}-9$ wt.\%Al, $\mathrm{Cu}-$ $10 \mathrm{wt} . \% \mathrm{Al}$ and $\mathrm{Cu}-11 \mathrm{wt} . \% \mathrm{Al}$ alloys it is possible to observe the phase transformations corresponding to higher Al concentration. The increase in the $\mathrm{Al}$ content decreases the $\alpha$ phase relative fraction and promotes the perlitic phase formation. The increase in the perlitic phase seems to facilitate the Ag diffusion. The increase in the $\mathrm{Al}$ concentration and the presence of $\mathrm{Ag}$ decrease the $\beta_{1}$ phase decomposition reaction rate and contribute for the increase in the temperature transition, thus decreasing the stability range of the perlitic phase, produced by the $\beta_{1}$ phase decomposition reaction. The results also indicate that this decomposition reaction seems to catalyze Ag precipitation.

\section{Acknowledgements}

The authors thank FAPESP and CNPq for financial support.

ADORNO, A. T.; BENEDETTI, A. V.; SILVA, R. A. G.; BLANCO, M.; Influência da concentração de Al nas transformações de fase em ligas de $\mathrm{Cu}-\mathrm{Al}-\mathrm{Ag}$.

\section{Resumo}

A influência da concentração de Al nas transformações de fase em ligas de $\mathrm{Cu}-\mathrm{Al}-\mathrm{Ag}$ foi estudada por análise térmica diferencial clássica (ATD), microscopia óptica (MO) e difratometria de raios $\mathrm{X}(\mathrm{DRX})$. Os resultados indicaram que o aumento no teor de $\mathrm{Al}$ e a presença de $\mathrm{Ag}$ diminuem a velocidade da reação de decomposição da fase $\beta 1$ e contribuem para o aumento da temperatura desta transição, diminuindo assim o intervalo de estabilidade da fase perlítica, resultante da reação de decomposição.

Palavra-chave: transformações de fase; transformação martensítica; ligas de $\mathrm{Cu}-\mathrm{Al}-\mathrm{Ag}$

\section{References}

[1] ADORNO, A. T.; GUERREIRO, M. R.; BENEDETTI, A. V. Influence of silver additions on the aging characteristics of the Cu-10.4at.\%Al alloys. J. Alloys Comp., v. 268, p. 122-129, 1998.

[2 ]ADORNO, A. T.; GUERREIRO, M. R.; BENEDETTI, A. V. Thermal behavior of $\mathrm{Cu}-\mathrm{Al}$ alloys near the $\alpha-\mathrm{Cu}-\mathrm{Al}$ solubility limit. J. Thermal Anal. Cal., v. 65, p. 221-229, 2001.

[3] ADORNO, A. T.; GUERREIRO, M. R.; RIBEIRO, C. A.; GUERREIRO, C. T. R. Influence of silver additions on the thermal behavior of the Cu-8wt.\%Al alloy. J. Thermal Anal. Cal., v. 64, p. 1141-1146, 2001.

[4] ARRUdA, G. J.; ADORNO, A. T.; MAGNANI, R.; BEATRICE, C. R. S. Kinetics of eutectoid decomposition in $\mathrm{Cu}-\mathrm{Al}$ and $\mathrm{Cu}-\mathrm{Al}-\mathrm{Ag}$ alloys. Mater. Lett., v. 32, p. 79-84, 1997.

[5] COPE, R. G. The tempering of martensite in copperaluminum alloys. J. Inst. Metals, v. 87, p. 330-336, 1959.

[6] GAUDIG, W.; WARLIMONT, H. The structure of short range ordered $\alpha-\mathrm{Cu}-\mathrm{Al}$ alloys and a new superlattice phase. Acta Metall., v. 26, p. 709-724, 1978.

[7] KWARCIAK, J. Phase transformation in $\mathrm{Cu}-\mathrm{Al}$ and Cu-Zn-Al alloys. J. Thermal Anal., v. 31, p. 559-566, 1986.

[8] KWARCIAK, J.; BOJARSKI, Z.; MORAWIEC, H. Phase transformation in martensite of $\mathrm{Cu}-12.4 \% \mathrm{Al}$. J. Mater. Sci., v. 21, p. 788-792, 1986.

[9] MASSALSKI, T. B. (Ed.). Binary alloy phase diagrams 
2nd. ed. Metals Park: American Society for Metals, v.1, p.141-143, 1992.

[10] MURRAY, J. L. The aluminum-copper system. Int. Met. Rev., v. 30, p. 211-233, 1985.

[11] RUZZANTES, J. E.; KUROKAWA, S.; GARCÌA, E. A.; DYMENT, F. Diffusion in the $\beta / \gamma 2$ interphase boundary of the Cu-Al system. Acta Metall., v. 28, p. 699-707, 1980.

[12] SWANN, P. R.; WARLIMONT, H. The electron metallography and crystallography of copper-aluminum martensites. Acta Metall., v. 11, p. 511-527, 1963 